AUTUMN STOMATAL CLOSURE IN SIX CONIFER SPECIES

OF THE CENTRAL ROCKY MOUNTAINS

W.K. Smith, D.R. Young, G.A. Carter,

J.L. Hadley and G.M. McNaughton

1984

Journal Article

WWRC-84-23

\author{
In \\ Oecologia (Ber1in) \\ Volume 63 \\ W.K. Smith \\ D.R. Young \\ G.A. Carter \\ J.L. Hadley \\ G.M. McNaughton \\ College of Botany \\ University of Wyoming \\ Laramie, Wyoming
}




\title{
Autumn stomatal closure in six conifer species of the Central Rocky Mountains
}

\author{
W.K. Smith, D.R. Young, G.A. Carter, J.L. Hadley, and G.M. McNaughton \\ Department of Botany, University of Wyoming, Laramie, WY 82071, USA
}

Summary. Environmental and water relations parameters during fall were monitored for six conifer tree species common to the central Rocky Mountains growing naturally at the same location (Pinus contorta, Pinus ponderosa, Pinus flexilus, Pseudotsuga menziesii, Abies lasiocarpa, Picea engelmannii). Subsequent to what appeared to be the beginning of seasonal stomatal closure, leaf conductance to water vapor declined sharply following the onset of freezing air temperatures at night. A coincident rapid decline in morning xylem pressure potentials $\left(\psi_{\mathrm{p}}\right)$ also occurred which resulted in values that were considerably below afternoon $\psi_{\mathrm{p}}$. Continuing decreases in maximum leaf conductance during the day were highly correlated with corresponding decreases in minimum nocturnal air temperatures of the preceding night. By mid-December, morning $\psi_{\mathrm{p}}$ returned to values very near afternoon $\psi_{\mathrm{p}}$ and were only slightly lower than before the onset of subfreezing nights. A preliminary model is proposed which interprets the qualitative interaction between air and soil temperatures, soil and plant water potentials, and leaf conductance during seasonal stomatal closure in fail.

Atmospheric factors which have been associated with stomatal behavior in conifers include air temperature, solar irradiance, and the leaf-to-air water vapor deficit (see Waring and Running 1976; Jarvis 1980; Kaufmann 1982a, b; Meinzer 1982a, b; Schulze and Hall 1982 for recent reviews). Recent attention has focused on the effects of cold air temperatures at night on stomatal closure the following day during spring and fall (Kaufmann 1976; 1982 b; Fahey 1979). Substantial decreases in $\mathrm{CO}_{2}$ assimilation rates following freezing nights have also been reported (Tranquillini 1957; Pisek and Kemnitzer 1968). In addition to the primary affects of solar irradiance and the vapor deficit, Kaufmann (1982b) proposed an empirical model for computing the influence of environmental factors on leaf conductance which included a term that reduced estimated leaf conductance in response to nighttime minimum temperatures that were below freezing. Numerous studies have also associated the influence of soil factors such as temperature and moisture on water status and leaf conductance in conifers during the growth season (e.g. Waring and Running 1976; Jarvis 1980; Running and Reid 1980; Schulze and Hall 1982).

Offprint requests to: W.K. Smith
The purpose of the present investigation was to evaluate environmental influences on seasonal stomatal closure in six species of central Rocky Mountain conifers. Specifically, changes in leaf conductance to water vapor and xylem pressure potentials were correlated with changes in air and soil temperatures, soil water potentials, and the leaf-to-air water vapor deficits that coincided with the onset of stomatal closure in fall. The influences of the above environmental and plant parameters were interpreted according to their interactive effects on leaf conductance. All six conifer species occurred naturally at the same study site, without any apparent differences in topography or edaphic factors.

\section{Methods}

The study site was located at an elevation of $2872 \mathrm{~m}$ in the Medicine Bow Mountains of southeastern Wyoming, U.S.A. $\left(41^{\circ} 21^{\prime} \mathrm{N}, 106^{\circ} 10^{\prime} \mathrm{W}\right)$. All of the six common conifer species of the central Rocky Mountains were found at the study site, growing within a radius of about $30 \mathrm{~m}$ from one another. The species were Pinus contorta Dougl. ex Loud. ssp. latifolia (Engelm.) Critchfield (lodgepole pine), Pinus ponderosa Dougl. (ponderosa pine), Pinus flexilis James (limber pine), Pseudotsuga menziesii ssp. glauca Franco (Douglas fir), Abies lasiocarpa Nutt. (subalpine fir), and Picea engelmannii Parry (Engelmann spruce). Three mature individuals of each species were selected for sampling according to size ( $>5 \mathrm{~m}$ tall) and genral appearance. All plant measurements were taken on clear, seasonably mild days following at least one day of similarly seasonable conditions. Thus, if significant stomatal opening were possible at this time of year, it would be expected to occur on these days.

Air temperature and relative humidity were recorded continuously during the study period (Sept 9-Dec. 2, 1982) using a hygrothermograph (Weather Measure model H311) located in a small clearing near the center of the research site ( $3 \mathrm{~m}$ height). Although the hygrothermograph was considerably lower than canopy heights (3-6 m), air temperature readings were similar to measuremtns taken at actual shoot locations using the leaf porometer described below $\left( \pm 2.2^{\circ} \mathrm{C}, \mathrm{n}=66\right)$. The hygrothermograph was calibrated weekly using a sling psychrometer. Subsurface soil water potentials and temperatures were measured at approximately $5,10,20,40 \mathrm{~cm}$ depths at four locations using soil thermocouple psychrometers (Wescor model PT 51-05 probes and model HR-33T dewpoint microvoltmeter). Surface soil 


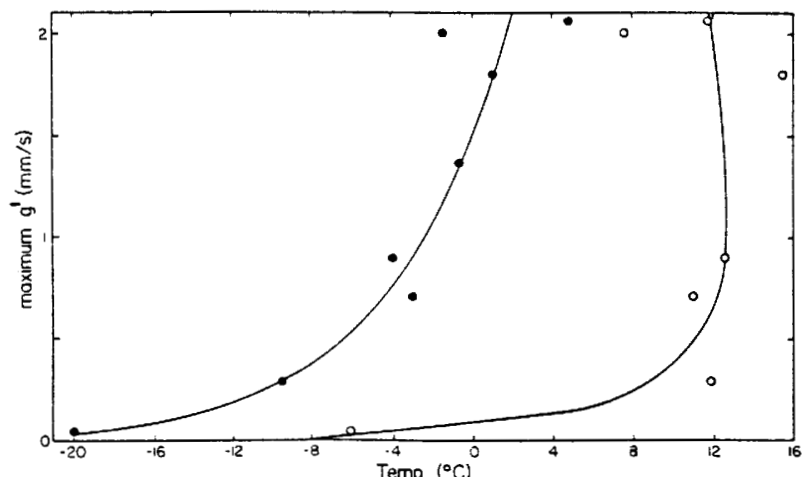

Fig. 2. Maximum daytime leaf conductances $\left(g^{1}\right)$ plotted versus the previous nights minimum air temperatures $(\bullet)$ and the maximum air temperatures for the same day of the $\mathrm{g}^{1}$ measurements (o)

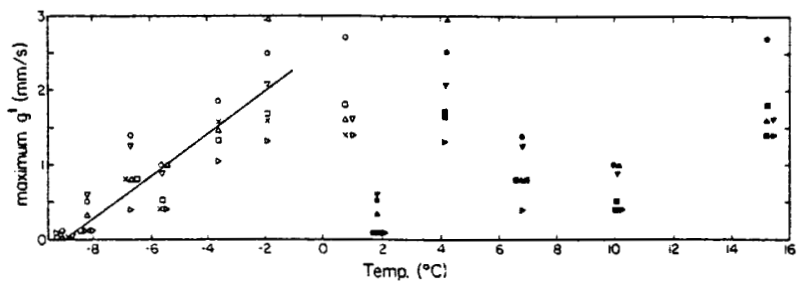

Fig. 3. Maximum daytime leaf conductance $\left(\mathrm{g}^{1}\right)$ plotted versus the absolute mean minimum air temperature for the three previous nights (closed symbols) and the mean maximum air temperature for the two previous days and same day of the $\left(\mathrm{g}^{1}\right)$ measurements (open symbols) (see Fig. 3 caption for symbol key). A regression line for the $\mathrm{g}^{1}$ and minimum night temperature data was statistically significant at $\alpha=0.05$ (ANOV) and generated a slope of $0.267 \mathrm{~mm} \mathrm{~s}^{-1}{ }^{\circ} \mathrm{C}^{-1}$ over the temperature interval of -1.0 to $-9.0^{\circ} \mathrm{C}$

very near zero for all six species and remained near zero on three subsequent measurement days in December. In general, Pinus contorta had consistently greater leaf conductances followed in order by $P$. ponderosa, $P$. flexilus, $P$ icea engelmannii, $A$. lasiocarpa, and $P$. menziesii. Comparing the maximum leaf conductance measured during the day (computed as the mean of all six species) to the minimum air temperature of the previous night showed a strong and significant curvilinear relationship $\left(\mathrm{r}^{2}=0.92,=0.05\right.$, Fig. 2$)$. A similar comparison with maximum daytime temperatures for the corresponding days of the leaf conductance measurements (seasonable days) resulted in a statistically nonsignificant relationship as well as a low correlation coefficient $\left(\mathrm{r}^{2}=0.21\right)$.

Comparing mean maximum leaf conductance for each species on a given day with the mean nighttime minimum temperature for the three previous nights resulted in a stronger linear correlation $\left(\mathrm{r}^{2}=0.90\right.$, Fig. 3$)$ than for only a single previous nights minimum temperature. The regression equation for these data predicted a decrease in maximum leaf conductance of about $0.25 \mathrm{~mm} \mathrm{~s}^{-10} \mathrm{C}^{-1}$ when nighttime temperatures dropped below about $-2^{\circ} \mathrm{C}$. A similar comparison of maximum leaf conductance with the 3-day mean maximum air temperatures during the day showed little correlation (Fig. 3).

Xylem pressure potentials $\left(\psi_{\mathrm{p}}\right)$ measured during early morning fell sharply between the Sept. 21 and Oct. 2 mea-

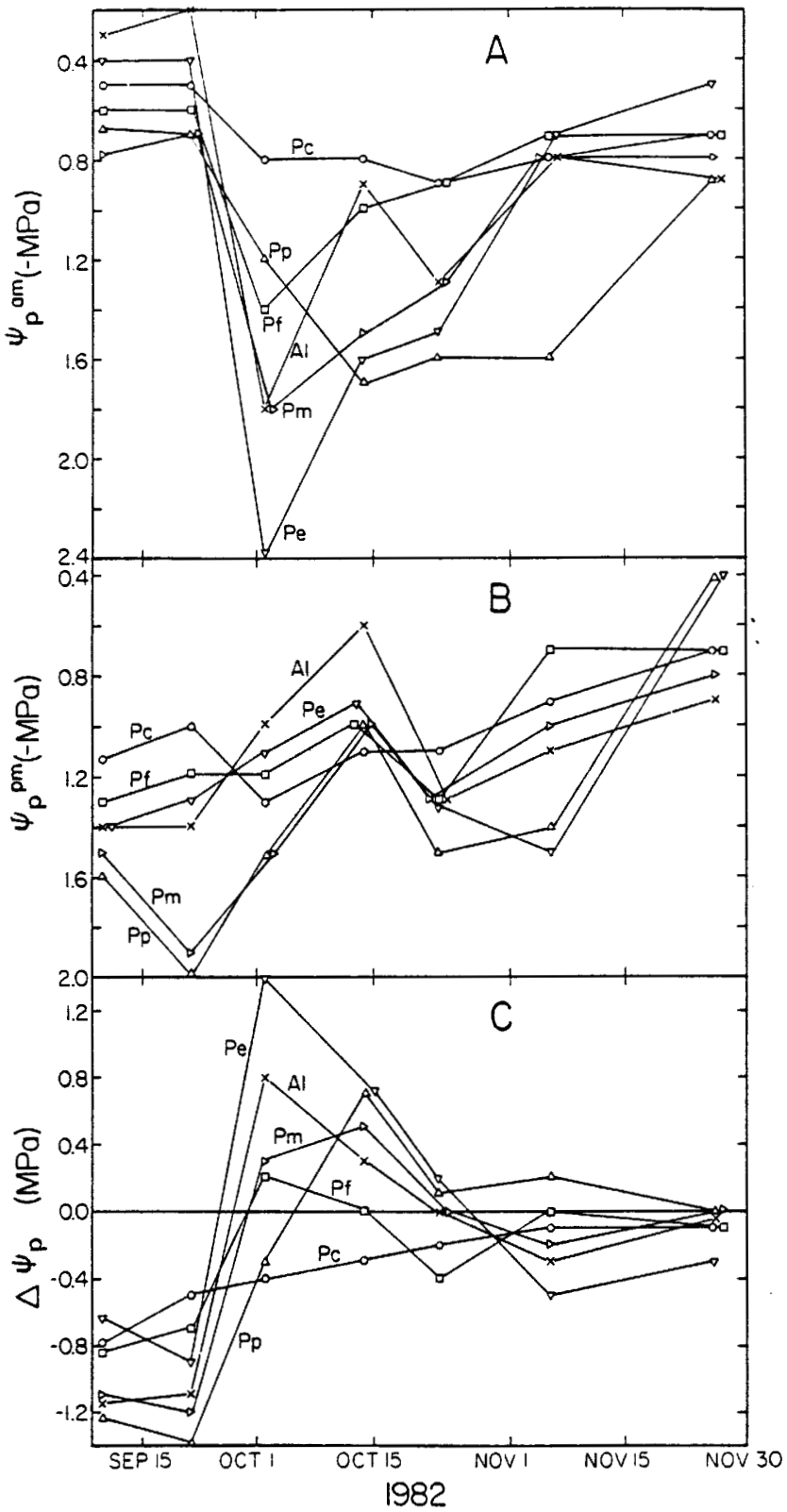

Fig. 4A-C. Mean xylem pressure potentials measured in A the early morning $\left(0700-0800, \psi_{\mathrm{p}}^{\mathrm{am}}\right)$, B afternoon $\left(1200-1330, \psi_{\mathrm{p}}^{\mathrm{pm}}\right)$, and C the difference between afternoon and morning $\psi_{\mathrm{p}}$ the six conifer species (see Fig. 3 caption for symbol key). Positive values indicate a more negative $\psi_{\mathrm{p}}^{\mathrm{am}}$ than $\psi_{\mathrm{p}}^{\mathrm{pm}}$

surement dates for all species except $P$. contorta (Fig. 4A). The greatest decline in morning $\psi_{\mathrm{p}}$ occurred in $P$. engelmannii followed by $A$. lasiocarpa and $P$. menziesii. This sharp decline was followed by a gradual increase in morning $\psi_{\mathrm{p}}$ until, by the end of November, all six species had early morning $\psi_{\mathrm{p}}$ values that ranged from about 0.1 to $0.6 \mathrm{MPa}$ less than September values. In contrast, $\psi_{\mathrm{p}}$ during the afternoon increased gradually, although with some variability, throughout the study period (Fig. 4B). Relatively large increases in afternoon $\psi_{\mathrm{p}}(0.8-0.9 \mathrm{MPa})$ occurred for $A$. lasiocarpa, $P$. menzienii, and $P$. ponderosa between Sept. 21 and Oct. 14.

Subtracting the mean afternoon $\psi_{\mathrm{p}}$ from early morning $\psi_{\mathrm{p}}\left(\Delta \psi_{\mathrm{p}}\right)$ showed that sometime between the Sept. 21 and 
Oct. 2 measurement dates morning $\psi_{\mathrm{p}}$ values fell considerably below afternoon values for all species except $P$. contorta (Fig. $4 \mathrm{C}$ ). On Oct. $2 \Delta \psi_{\mathrm{p}}$ was greatest for $P$. engelmannii (1.3 MPA) followed by $A$. lasiocarpa $(0.8 \mathrm{MPa})$ and $P$. menzienii $(0.35 \mathrm{MPa})$. $P$. contorta had a gradual increase in $\Delta \psi_{\mathrm{p}}$ until the end of the study period when $\Delta \psi_{\mathrm{p}}$ for all species was within $-0.3 \mathrm{MPa}$ of zero, indicating little differences between afternoon and morning $\psi_{\mathrm{p}}$ (Fig. 4C).

\section{Discussion}

Although all six conifer species had different values of maximum leaf conductances in early fall, similar patterns of decreasing conductances were evident throughout October and Novemeber (Fig. 1). A strong curvilinear relationship developed between the minimum air temperature at night and the maximum daytime conductance for the following day immediately following the onset of subfreezing nights (Figs. 1 and 2). Averaging the minimum air temperatures that occurred over the three previous nights resulted in a significent linear relationship between minimum nighttime air temperatures and leaf conductances (Fig. 3). Also, there were no apparent correlations between maximum leaf conductance and maximum daytime temepratures (Fig. 2 and 3 ) or minimum vapor pressure deficits. Early morning water status also responded dramatically to the onset of freezing nights with a major decrease in morning $\psi_{\mathrm{p}}$ (Fig. 4). For the remainder of the study period, morning $\psi_{\mathrm{p}}$ progressively increased to levels near afternoon $\psi_{\mathrm{p}}$.

Kaufmann (1982a, b) proposed a phenomenological model of conifer leaf conductance which incorporated solar irradiance and the vapor deficit between the leaf and air as primary environmental factors. Temperature and water stress were considered secondary, but seasonally important factors. More specifically, Kaufmann (1982 b) reported significant reductions in leaf conductance during late summer following nighttime minimum air temperature below about $4^{\circ} \mathrm{C}$. Kaufmann (1976) and Fahey (1979) reported a similar relationship between conifer leaf conductance and nighttime air temperatures in early spring. Also, Walker and Zelitch (1963) and Drew and Bazzaz (1979) found that cold nights lead to decreased leaf conductance in broadleaf species.

To our knowledge, no investigators have attempted to develop an interactive model of environmental constraints on stomatal opening during the seasonal transition periods of Spring and Fall. These transition periods may be especially important to high elevation species where a large portion of the total growth season may overlap these periods. According to the results presented here, decreases in leaf conductance as well as major decreases in morning $\psi_{\mathrm{p}}$ (above afternoon $\psi_{\mathrm{p}}$ ) for all six species occurred to varying degrees after the onset of freezing nights in early Fall. Afternoon $\psi_{\mathrm{p}}$ was considerably more variable among the species, but increased gradually over the study period. Also, morning $\psi_{\mathrm{p}}$ gradually increased to levels that were only slightly lower than before the onset of freezing nights. The onset of subfreezing nocturnal air temperatures and the coincident changes in $\psi_{\mathrm{p}}$ would be expected to potentially influence stomatal behavior. Based on the above data and the findings of other investigators, we have proposed an interactive system for environmental influences on seasonal stomatal closure which is illustrated schematically in Fig. 5.

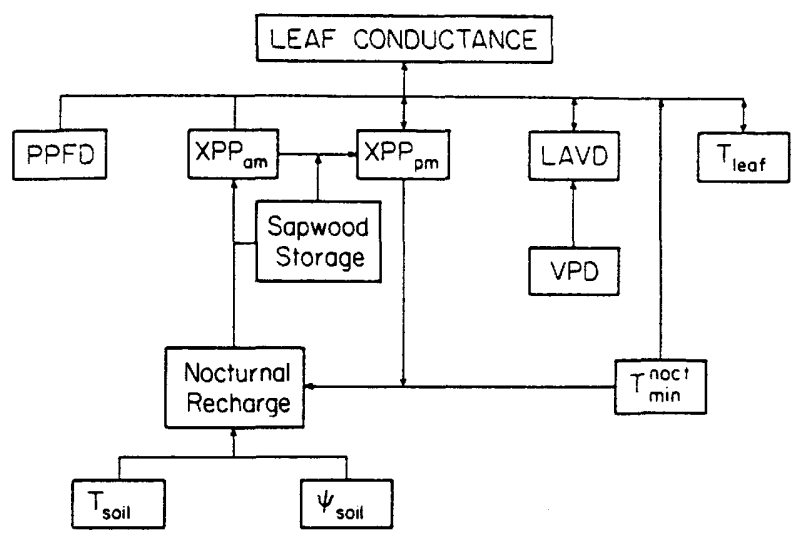

Fig. 5. Primary interactions between plant and environmental factors that have been identified in the literature (see text) and may have strong influences on leaf conductance during stomatal closure in Fall. Environmental factors: photon flux density, PPFD; vapor deficit of the air (VPD) and from the leaf-to-air (LAVD); leaf temperature minimum air temperature at night $\left(T_{\min }^{\text {noct }}\right)$; soil temperature $\left(\mathrm{T}_{\text {soil }}\right)$ and water potential $\left(\psi_{\text {soii }}\right)$. Plant parameters: xylem pressure potential in the morning $\left(\psi_{\mathrm{p}}^{2 \mathrm{~m}}\right)$ and afternoon $\left(\psi_{\mathrm{p}}^{\mathrm{pm}}\right)$; sapwood water storage; leaf temperature; nocturnal recharge mechanisms for water uptake

According to this interpretation, leaf conductance is influenced by the now well known effects of solar irradiance; soil and plant water status; leaf-to-air vapor deficit (LAVD); and effects due to air, leaf, and soil temperature variations, all of which have been previously reported for numerous species besides conifers (See Schulze and Hall 1982 review). However, we have now included an interactive interpretation of the observed changes in leaf conductance for the seasonal transition period in early Fall. As freezing nights begin to occur, there appears to be a documented, direct effect on stomatal opening the following day (Walker and Zelitch 1963, Kaufmann 1976, Fahey 1979, Drew and Bazzaz 1979), but also a possible indirect influence via decreases in morning $\psi_{\mathrm{p}}$ (Fig. 5). This decrease in morning $\psi_{\mathrm{p}}$ may be due to an inhibition of sapwood water movement during the night which may be linked to the cold temperature of the above ground tissue. Zimmerman (1964) found that stem temperatures below about $-2^{\circ} \mathrm{C}$ stopped the ascent of sap in conifers. As indicated in Fig. 5, a similar reduction in soil water uptake by the roots may also occur when soil temperatures are low (Kaufmann 1975, Dalton and Gardner 1978, Running and Reid 1980, Teskey et al. 1983). Other recent work has found a strong correlation between maximum daily leaf conductance and soil temperatures for $A$. lasiocarpa and $P$. engelmannii growing at high elevations (Carter et al. 1984). Leaf conductance during the summer increased dramatically to maximum values during mid-August at the same time warming soil temperatures at $25 \mathrm{~cm}$ approached $7^{\circ} \mathrm{C}$. A similar value of near $7^{\circ} \mathrm{C}$ was found to be near a limiting threshold for root resistance to water uptake in P. engelmannii (Kaufmann 1975). Running and Reid (1980) also observed an approximate $7^{\circ} \mathrm{C}$ threshold for increased root conductance to water uptake in $P$. contorta seedlings. Recently, Teskey et al. (1983) reported that cold root temperatures resulted in stomatal closure that was independent of leaf water potential in Abies amabilis. 
Referring again to Fig. 5, the indirect effects of soil temperature and soil water potential on nocturnal water recharge and, thus, morning $\psi_{p}$ may be mediated somewhat by the capacity for water storage in the sapwood and the leaf conductance and transpiration rate of the preceeding day. Running (1980) estimated that sapwood water storage in $P$. contorta could support about $0.6 \mathrm{hr}$ of maximum transpiration and $4.7 \mathrm{hr}$ of minimum transpiration. Leaf conductance is a primary determinant of the afternoon $\psi_{p}$, but may also influence the following morning $\psi_{\mathrm{p}}$, depending on the capacity for nocturnal water uptake. Thus, leaf conductance may have a primary influence of afternoon $\psi_{p}$, while air and soil temperatures may have a more direct influence on morning $\psi_{\mathrm{p}}$. Differences among species in sapwood water storage capabilities could also exert an important influence on maximum leaf conductance values and $\psi_{\mathrm{p}}$, especially afternoon $\psi_{\mathrm{p}}$ (Waring and Running 1978; Running 1980).

Applying the interactions in Fig. 5 to the data presented in Figs. 2-4 provides a possible interpretation of the primary environmental factors that may be influencing seasonal stomatal closure during Fall, and, possibly, seasonal stomatal opening in Spring. With the onset of near freezing nighttime air temperatures, water movement in the xylem may have been restricted in above-ground tissue which led to the concurrent decreases in morning $\psi_{\mathrm{p}}$. However, the ensuing decreases in leaf conductance in response to the cold nighttime air temperatures and the lower morning $\psi_{\mathrm{p}}$, gradually led to a return of higher morning $\psi_{\mathrm{p}}$ and, thus, more similar morning and afternoon $\psi_{\mathrm{p}}$ (Fig. 5). The gradual increase in afternoon $\psi_{\mathrm{p}}$ would be anticipated as a result of the decreasing leaf conductance values during the day.

The contribution of cold soil temperatures to the sharp decrease in leaf conductance and $\psi_{\mathrm{p}}$ during the first part of October (Fig. 1 and 4) may have been secondary to cold air temperatures. At 5 and $20 \mathrm{~cm}$ depths, freezing soil temperatures did not occur during the study period, and temperatures of near $7^{\circ} \mathrm{C}$ did not occur until after Nov. 4 (Fig. 1B).

Although the influence of cold soil temperatures and low soil water potential may have not been of primary importance, due to the relatively warm and wet soil at this lower elevation site, these factors may be of greater importance at higher elevations and more normal precipiation summers than occurred in 1982. At higher elevations in the forest, cooler soil temperatures may be more of a limiting factor and soil water potential less due to increased snowpack. In contrast, stomatal behavior for species growing in windy. exposed areas such as found in timberline zones may experience considerably greater soil moisture stress due to a lack of surface snow accumulation, while soil temperatures would be warmer due to greater insolation.

Soil temperatures at root depths could be expected to lag behind air temperature variations in both the warming period in spring and the cooling trend of fall. Thus, influences of less than optimal soil temperatures on stomatal conductance may be prolonged in spring, but minimal in fall when cold air temperatures are the primary cause of permanent stomatal closure. More infomration is needed which correlates any apparent threshold or graded changes in leaf conductance in response to seasonal air and soil temperature patterns.

Again, becaluse trees living at particularly high eleva- tions may experience a large part of their growth season in the transitional states of breaking and entering winter dormancy, the seasonal model depicted in Fig. 5 may actually describe the stomatal behavior and water relations of a large portion of their growth period. Moreover, specific differences in their stomatal responses to environmental conditions in spring and fall could lead to such important differences among species as total seasonal carbon gain during an already abbreviated growth season.

\section{References}

Cowan IR (1979) Stomatal behavior and environment. Adv Bot Res 4:117-227

Dalton FN, Gardner WR (1978) Temperature dependence of water uptake by plant roots. Agron J 70:404-406

Drew AP, Bazzaz FA (1979) Response of stomatal resistance and photosynthesis to night temperature in Populus deltoides. Oecologia (Berlin) 41:89-98

Fahey TJ (1979) The effect of night frost on the transpiration of Pinus contorta ssp. latifolia. Oecol Plant 14:483-490

Jarvis PG (1980) Stomatal response to water stress in conifers. In: Turner NC, Kramer PJ (eds) Adaptation of plants to water and high temperatures stress. John Wiley and Sons, pp 105122

Kaufmann MR (1968) Water relations of pine seedlings in realtion to root and shoot growth. Plant Physiol 43:281-288

Kaufmann MR (1976) Stomatal response of Engelmann spruce to humidity, light, and water stress. Plant Physiol 57:898901

Kaufmann MR (1979) Stomatal control and development of water deficit in Engelmann spruce seedlings during drought. Can J Forest Res 9:297-304

Kaufmann MR (1982a) Leaf conductance as a function of photosynthetic photon flux density and absolute humidity difference from leaf to air. Plant Physiol 69:1018-1022

Kaufmann MR (1982b) Evaluation of season, temperature, and water stress effects on stomata using a leaf conductance model. Plant Physiol 69:1023-1026

Kaufmann MR, Eckard AN (1977) A portable instrument for rapidly measuring conductance and transpiration of conifers and other species. Forest Sci $23: 227-237$

List RJ (1968) Smithsonian meteorological tables. Smithsonian Institution Press, Washington, DC p 527

Meinzer FC (1982a) The effect of vapor pressure on stomatal control of gas exchange in Douglas fir (Pseudotsuga menziesii) saplings. Oecologia (Berlin) 54:236-242

Meinzer FC (1982b) The effect of light on stomatal control of gas exchange in Douglas fir (Pseudotsuga menziesii) saplings. Oecologia (Berlin) 54:270-274

Nobel PS (1983) Biophysical Plant Physiology and Ecology. W. H. Freeman, San Francisco

Pisek A, Kemnitzer R (1968) Der Einfluß von Frost auf die Photosynthese der Weißtanne (Abies alba Mill.) Flora (Jena) $157: 314-326$

Running SW (1980) Relating plant water capacitance to the water relations of Pinus contorta. Forest Ecol Man 2:237-252

Running SW, Reid CP (1980) Soil temperature influences on root resistance of Pinus contorta seedlings. Planta Physiol 65:635-640

Schulze ED. Hall AE (1982) Stomatal responses, water loss of $\mathrm{CO}_{2}$ assimilation rates of plants in contrasting environments pp 181-231 In: OL Lange, PS Nobel. CB Osmond. H Ziegler (eds) Physiological plant ecology II : water relations and carbon assimilation. Springer, NY, pp 181-230

Teskey RO. Hinckley TM, Grier CG (1983) Effect of interruption of flow path on stomatal conductance of Abies amahilis. J Exp Bot 34: 1251-1259

Tranquillini W (1957) Standortsklima, Wasserbilanz und $\mathrm{CO}_{2-}$ 
Gaswechsel junger Zirben (Pinus cembra L.) an der alpinen Waldgrenze. Planta 49:612-661

Walker DA, Zelitch I (1963) Some effects of metabolic inhibitors, temperature, and anaerobic conditions on stomatal movements. Plant Physiol 38:390-396

Waring RH, Running SW (1978) Sapwood water storage: its contribution to transpiration and effect upon water conductance through the stems of old growth Douglas fir. Plant Cell Environ $1: 131-140$
Waring RH, Running SW (1976) Water uptake, storage and transpiration in conifers: a physiological model. In: OL Lange, L Kuppen, E-D Schulze (eds) Water and plant life, Springer, NY, pp 189-202

Zimmermann MH (1964) Effect of low temperature on ascent of sap in trees Plant Physiol 39:568-572

Received March 16, 1984 